BADANIA I ROZWÓJ

\author{
mł. bryg. dr inż. Mariusz Pecio ${ }^{a}$
}

a)Szkoła Główna Służby Pożarniczej / The Main School of Fire Service

*Autor korespondencyjny / Corresponding author: mariusz.pecio@gmail.com

\title{
Analiza wybranych aspektów bezpieczeństwa pożarowego oraz przygotowania operacyjnego Starego Miasta w Warszawie
}

\author{
Analysis of Selected Aspects of Fire Safety and Operating Capability in Warsaw's Old Town \\ Анализ отдельных аспектов пожарной безопасности Старого города в Варшаве \\ и оперативной подготовки к проведенню спасательно-гасящих действий
}

\begin{abstract}
ABSTRAKT
Cel: Celem artykułu jest analiza aktualnego poziomu bezpieczeństwa pożarowego oraz przygotowania operacyjnego do prowadzenia działań ratowniczogaśniczych na terenie historycznego centrum Warszawy. Dodatkowo w pracy określono rozwiązania techniczne, operacyjne i legislacyjne, które mogą przyczynić się do poprawy sytuacji w dwóch wyżej wymienionych obszarach.

Wprowadzenie: W artykule przedstawiono ocenę bezpieczeństwa pożarowego oraz przygotowania operacyjnego do działań ratowniczo-gaśniczych terenu Starego Miasta w Warszawie. W tym celu wykorzystano analizę dostępnych materiałów źródłowych, danych statystycznych, wyników badań ankietowych oraz obowiązujących aktów prawnych. Elementem wprowadzenia do przedmiotowego zagadnienia jest również charakterystyka dzielnicy Stare Miasto w Warszawie, w której uwzględniono przynależność tego obszaru do światowego dziedzictwa narodowego UNESCO.

Metodologia: Artykuł zawiera ocenę wybranych aspektów bezpieczeństwa pożarowego Starego Miasta w Warszawie oraz przygotowania operacyjnego KM PSP w Warszawie tego obszaru. Ocena bezpieczeństwa pożarowego została przeprowadzona przy wykorzystaniu analizy materiałów zgromadzonych podczas pracy przy programie HERITPROT, danych uzyskanych od Komendy Miejskiej PSP w Warszawie oraz na podstawie wyników badań ankietowych. Badania ankietowe przeprowadzono wśród wszystkich obecnych na Starym Mieście administratorów nieruchomości mieszkalnych oraz wszystkich występujących na tym terenie administratorów budynków sakralnych. Analiza przygotowania operacyjnego do prowadzenia działań ratowniczo-gaśniczych objęła weryfikację zgodności z wymaganiami dróg pożarowych oraz przeciwpożarowego zaopatrzenia w wodę. Na podstawie przeprowadzonej analizy zaproponowano metody zwiększenia bezpieczeństwa miejskich starówek. Do proponowanych działań organizacyjnych należą szkolenia jednostek ratowniczo-gaśniczych. Rozwiązania techniczne to nowoczesne urządzenia gaśnicze (mgła wodna), natomiast działania legislacyjne obejmują dostosowanie zasad opracowywania instrukcji bezpieczeństwa pożarowego dla budynków zabytkowych.

Wnioski: Wykazano, że problemy związane z odpowiednim zabezpieczeniem wrażliwego, historycznego obszaru miejskiego oraz zabytkowych eksponatów można rozwiązywać z wykorzystaniem urządzeń technicznych lub uwarunkowań prawnych. Artykuł zawiera przykłady działań pozwalających poprawiać stan bezpieczeństwa pożarowego na starówkach miejskich oraz przykłady rozwiązań służących polepszeniu przygotowania tych obszarów do prowadzenia akcji ratowniczo-gaśniczej. Dodatkowo kompleksowa ocena stanu dróg pożarowych i przeciwpożarowego zaopatrzenia w wodę może być bezpośrednio wykorzystana do działań operacyjnych Komendy Miejskiej PSP w Warszawie.
\end{abstract}

Słowa kluczowe: bezpieczeństwo pożarowe, przygotowanie operacyjne, zabezpieczenie terenu, Warszawa, Stare Miasto, UNESCO

Typ artykułu: artykuł przeglądowy

Przyjęty: 06.02.2016; Zrecenzowany: 17.05.2017; Opublikowany: 30.06.2017;

Proszę cytować: BiTP Vol. 46 Issue 2, 2017, pp. 88-98, doi: 10.12845/bitp.46.2.2017.6;

Artykuł udostępniany na licencji CC BY-NC-SA 4.0 (https://creativecommons.org/licenses/by-nc-sa/4.0/)

\section{ABSTRACT}

Aim: This article aims to analyse the current level of fire safety and operating preparation for conducting rescue and firefighting operations within the Historical Centre of Warsaw. The aim of the study is also to determine the technical, operating and legislative activities which can improve the situation in the two aforementioned areas.

Introduction: The article presents an assessment of fire safety and the preparation for fire and rescue operations in the Old Town in Warsaw. For this purpose, the paper analyses the available source materials, statistical data, survey results and existing legislation. As an introduction to the subject, the article describes the Old Town district of Warsaw, including its recognition as a world heritage site by the UNESCO. 
Methodology: The article contains an assessment of selected aspects of fire safety in Warsaw's Old Town and an evaluation of the preparation of the Municipal Headquarters of the State Fire Service in Warsaw for carrying out operations in this area. The assessment of fire safety was performed using the analysis of materials collected while working with the HERITPROT project, data obtained from the Municipal Headquarters of the State Fire Service in Warsaw and on the basis of survey results. A survey was also carried out among all residential property administrators in the Old Town and all administrators of religious buildings in this area. The analysis of the preparation for rescue and firefighting operations included an assessment of compliance with the requirements of fire access roads and fire water supply. The analysis proposes ways of increasing the safety of Old Town areas in cities. Organisational activities include training for fire and rescue units; technical solutions comprise modern firefighting equipment (water fog); and legislative action involves the adaptation of Fire Safety Instructions for historic buildings.

Conclusions: The analysis showed that problems with an inadequate protection of sensitive historic urban fabric and historical exhibits can be solved by using either technical devices or legal conditions. Hence, the article includes examples of activities for improving fire safety in Old Town areas, and examples of solutions for improving the preparation of these areas for conducting rescue and firefighting operations. In addition, the contained comprehensive assessment of fire access roads and fire water supply can be directly used for operating activities of the Municipal Headquarters of the State Fire Service in Warsaw.

Keywords: fire safety, operating capability, site protection, Old Town in Warsaw, UNESCO

Type of article: review article

Received: 06.02.2016; Reviewed: 17.05.2017; Published: 30.06.2017;

Please cite as: BiTP Vol. 46 Issue 2, 2017, pp. 88-98, doi: 10.12845/bitp.46.2.2017.6;

This is an open access article under the CC BY-NC-SA 4.0 license (https://creativecommons.org/licenses/by-nc-sa/4.0/).

\section{АННОТАЦИЯ}

Цель: Целью данной статьи является анализ текушего состояния пожарной безопасности и оперативной подготовки к проведению спасательногасяших действий на территории исторического центра Варшавы. Цель работы заключается также в определении технических, оперативных и законодательных решений, которые могут способствовать улучшению ситуации в двух вышеуказанных сферах.

Введение: В статье была представлена оценка пожарной безопасности и оперативной подготовки к спасательно-гасяшим действиям на территории Старого города в Варшаве. Для этой цели был использован анализ имеюшихся исходных материалов, статистических данных, результатов опросов и действуюшего законодательства. Частью введения к рассматриваемой теме является также характеристика района Старого города в Варшаве, в том числе в контексте его принадлежности к всемирному наследию ЮНЕСКО.

Методология: Статья содержит оценку отдельных аспектов пожарной безопасности Старого города в Варшаве, а также оценку оперативной подготовки Городской комендатуры ГПС в Варшаве в этой области. Оценка пожарной безопасности была проведена с использованием анализа материалов, собранных в ходе работы с программой HERITPROT, данных из Городской комендатуры ГпС в Варшаве и на основе результатов опроса. Опрос был проведен среди всех присутствуюших в Старом городе администраторов жилой недвижимости и всех администраторов зданий религиозного характера, находяшихся в этом районе. Анализ оперативной подготовки к проведению спасательно-гасяших действий включал оценку соответствия с требованиями об обеспечении пожарных дорог и противопожарного водоснабжения. На основе проведенного анализа были предложены способы повышения безопасности старых городских центров. Организационными мероприятиями являются тренинги спасательно-гасяших подразделений, а техническими решениями - современное противопожарное оборудование (водяной туман). В то же время законодательственные решения включают в себя адаптацию Инструкции пожарной безопасности для исторических зданий.

Выводы: Было обнаружено, что проблемы, связанные с соответствуюшей зашитой, уязвимой исторической части города и исторических экспонатов, могут быть решены с помошью технических устройств или правовых решений. В статье приводятся примеры действий, позволяюших повышать пожарную безопасность в старых городских центрах и примеры решений для улучшения подготовки этих районов для проведения спасательно-гасяших действий. Кроме того, комплексная оценка состояния противопожарных дорог и противопожарного водоснабжения может быть непосредственно использована для оперативных действий Городской комендатуры ГпС в Варшаве.

Ключевые слова: пожарная безопасность, оперативная подготовка, зашита территории, Варшава Старый город, ЮНЕСКО

Вид статьи: обзорная статья

Принята: 06.02.2016; Рецензирована: 17.05.2017; Опубликована: 30.06.2017;

Просим ссылаться на статью следуюшим образом: BiTP Vol. 46 Issue 2, 2017, pp. 88-98, doi: 10.12845/bitp.46.2.2017.6;

Настояшая статья находится в открытом доступе и распространяется в соответствии с лицензией CC BY-NC-SA 4.0

(https://creativecommons.org/licenses/by-nc-sa/4.0/). 


\section{Wprowadzenie}

Celem artykułu jest ocena bezpieczeństwa pożarowego oraz przygotowania do prowadzenia akcji ratowniczo-gaśniczej terenu Starego Miasta w Warszawie. Analizie poddano materiały zgromadzone podczas pracy przy programie HERITPROT, wyniki badań ankietowych, wizji lokalnej, dane statystyczne Komendy Głównej Państwowej Straży Pożarnej (KG PSP), Komendy Miejskiej Państwowej Straży Pożarnej m. st. Warszawy (KM PSP Warszawy) oraz dostępna literatura tematu. Program HERITPROT pt. „Przeciwdziała- nie Ryzyku Pożarowemu i Doskonalenie Systemów Gaszenia Pożarów Starówek Miejskich uznanych za obiekty Światowego Dziedzictwa Kulturowego UNESCO" był współfinansowany ze środków Europejskiego Funduszu Rozwoju Regionalnego w ramach programu INTERREG IVC [1].

Program ten zainicjowano jako reakcję na pożar, który w 2006 roku zniszczył XVII-wieczny pałac Salazar w mieście La Laguna na Teneryfie. Miał on zapoczątkować dyskusję i pomóc w znalezieniu rozwiązań pozwalających ograniczyć ryzyko pożarowe na starówkach miejskich w Europie. Pałac Biskupi Salazar oraz akcję gaśniczą z 2006 roku pokazano na rycinach 1 i 2.

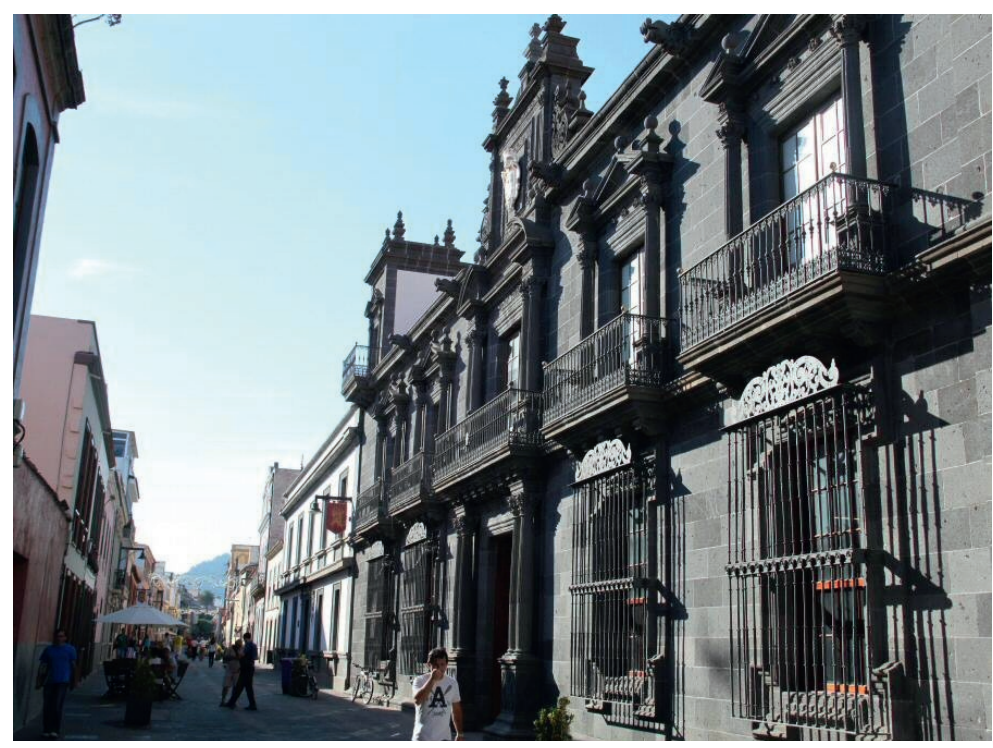

Rycina 1. Pałac Biskupi Salazar w La Laguna

Figure 1. Salazar Palace in La Laguna

Źródło: http://guias-viajar.com/espana/tenerife-fotos-la-laguna/.

Source: http://guias-viajar.com/espana/tenerife-fotos-la-laguna/.

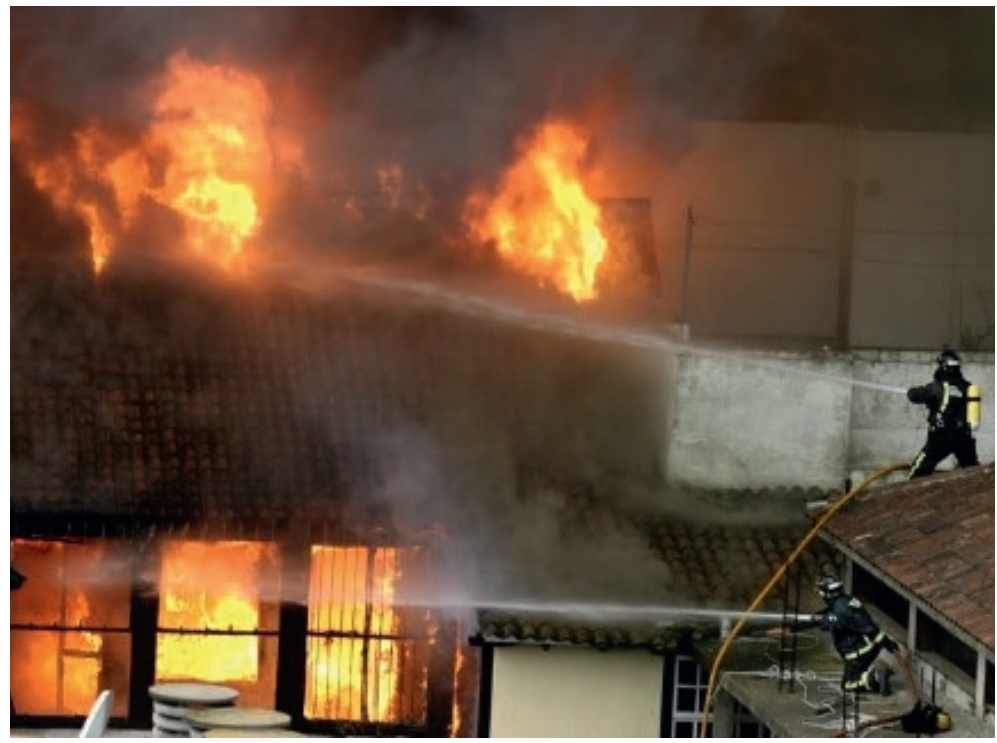

Rycina 2. Akcja gaśnicza Pałacu Salazar

Figure 2. Firefighting at the Salazar Palace

Źródło: http://www.20minutos.es/noticia/ 84070/0/ESPANA/INCENDIO/TENERIFE/.

Source: http://www.20minutos.es/noticia/ 84070/0/ESPANA/INCENDIO/TENERIFE/. 
Artykuł prezentuje ogólną charakterystykę Starego Miasta w Warszawie z uwzględnieniem wpisania tego obszaru na listę światowego dziedzictwa UNESCO, ocenę bezpieczeństwa pożarowego Starego Miasta w Warszawie oraz ocenę przygotowania operacyjnego tego obszaru. W pracy zawarto również przykładowe rozwiązania (techniczne i legislacyjne), które mogą wpłynąć pozytywnie na poziom bezpieczeństwa pożarowego starówek miejskich.

\section{Charakterystyka ogólna Starego Miasta w Warszawie}

Stare Miasto w Warszawie jest najstarszym ośrodkiem miejskim Warszawy będącym zwartym zespołem architektury zabytkowej o średniowiecznym układzie zabudowy, głównie z XVII i XVIII wieku. Jest ono otoczone pierścieniem murów obronnych z XIV-XVI wieku, a jego rynek rozmieszczony jest na planie prostokąta. Stara Warszawa była miastem królewskim Korony Królestwa Polskiego. Plan Starego Miasta z lokalizacją jego najważniejszych obiektów przedstawiono na rycinie 3 .

2 września 1980 roku Stare Miasto w Warszawie zostato umieszczone na liście światowego dziedzictwa UNESCO (na pozycji 30). Warszawska Starówka znalazła się na tej liście jako przykład niemal kompletnej rekonstrukcji. W tekście wyjaśniającym napisano [2]: „Ponad 85\% zabytkowego centrum Warszawy zostało zniszczone przez nazistowskie oddziały okupacyjne. Po wojnie mieszkańcy Warszawy podjęli dzieło odbudowy, które doprowadziło do odtworzenia kościołów, pałaców i domów będących symbolem polskiej kultury i narodowej tożsamości. Jest to wyjątkowy przykład całkowitej rekonstrukcji zespołu historycznego".

\section{Ocena bezpieczeństwa pożarowego}

\section{Kontrole Państwowej Straży Pożarnej}

Na podstawie informacji uzyskanych z Komendy Miejskiej PSP w Warszawie ustalono, że w latach 2003-2012 przeprowadzono 24 kontrole stanu bezpieczeństwa pożarowego budynków na terenie Starego Miasta. Otrzymane częściowe wyniki kontroli przedstawiono $w$ tabeli 1.

Z przeprowadzonej analizy wynikają następujące syntetyczne wnioski:

- stwierdzono łącznie 5 niezgodności związanych z wymaganiami ewakuacyjnymi oraz składowaniem materiałów palnych,

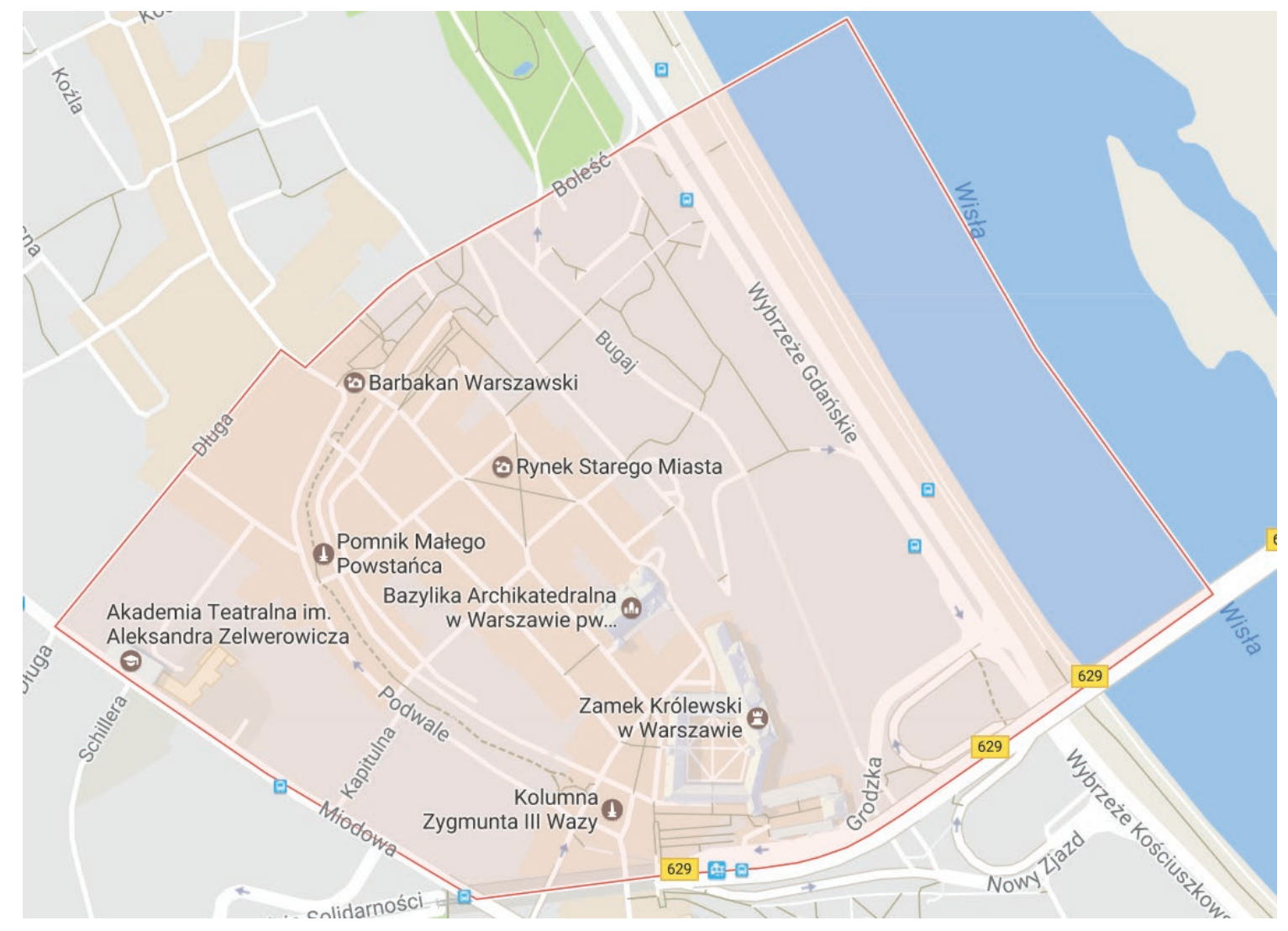

Rycina 3. Plan Starego Miasta w Warszawie z oznaczonymi najważniejszymi zabytkami

Figure 3. Plan of the Old Town in Warsaw with the most important historic objects marked

Źródło: https://www.google.pl/maps.

Source: https://www.google.pl/maps. 
- w 14 kontrolowanych budynkach nie występuje instalacja hydrantowa, nie zawarto informacji na temat instalacji hydrantowej w pozostałych obiektach,

- w 4 budynkach (co stanowi poniżej 17\%) występują instalacje i urządzenia przeciwpożarowe (SSP, DSO), przy czym w 2 budynkach występuje jedna instalacja i w 2 obiektach stwierdzono po dwie instalacje.

Należy ocenić, iż stan bezpieczeństwa pożarowego, będący obrazem przeprowadzonych kontroli, nie odbiega znacząco od poziomu bezpieczeństwa pożarowego charakterystycznego dla całej Warszawy. Przypadki związane z występowaniem warunków stanowiących podstawę do uznania budynku za zagrażający życiu ludzi $[4, \S 16$, ust. 2] stwierdzono w dwóch przypadkach (zawężenie szerokości spoczników oraz przekroczenie dopuszczalnej długości dojścia ewakuacyjnego).

Większość kontroli miała na celu sprawdzenie przestrzegania przepisów przeciwpożarowych (budynki istniejące). Kontrole odbiorowe (dot. budynków nowych lub modernizowanych) miały nieznaczny udział w czynnościach kontrolnych. W przypadku kontroli przestrzegania przepisów przeciwpożarowych dopuszcza się występowanie pewnych niezgodności (oprócz przypadków zagrożenia życia) z przepisami obowiązującymi obecnie, co po części tłumaczy stosunkowo niewielką liczbę niezgodności. Taka sytuacja jest w obszarze Starego Miasta naturalna, ponieważ z uwagi na charakter obszaru, budowanie nowych obiektów oraz modernizowanie istniejących jest objęte wieloma restrykcjami.

Tabela 1. Wyniki kontroli stanu bezpieczeństwa pożarowego w budynkach na terenie Starego Miasta w latach 2003-2012

Table 1. The results of fire safety inspections in the Old Town buildings in 2003-2012

\begin{tabular}{|c|c|c|c|c|c|c|c|c|}
\hline $\begin{array}{l}\text { Lp. I } \\
\text { No }\end{array}$ & $\begin{array}{l}\text { Rodzaj budynku / } \\
\text { Building type }\end{array}$ & $\begin{array}{l}\text { Wysokość / } \\
\text { Height }\end{array}$ & $\begin{array}{l}\text { Nieprawidłowości / } \\
\text { Incompatibilities }\end{array}$ & $\begin{array}{l}\text { Hydranty I } \\
\text { Hydrants }\end{array}$ & $\begin{array}{l}\text { SSP I } \\
\text { FD }\end{array}$ & $\begin{array}{c}\text { SUG / } \\
\mathrm{EE}\end{array}$ & $\begin{array}{l}\text { DSO I } \\
\text { VS }\end{array}$ & Dojście / Routes \\
\hline 1. & $\begin{array}{l}\text { budynek mieszkalny } \\
\text { / residential building }\end{array}$ & $x$ & $x$ & $x$ & $x$ & $x$ & $x$ & $x$ \\
\hline 2. & teatr / theatre & sW & $x$ & - & - & - & - & $\begin{array}{l}\text { przekroczona o } 100 \%-\text { ZŻ I } \\
\text { exceeded by } 100 \%-Z \dot{Z}\end{array}$ \\
\hline 3. & urząd / government office & $\mathrm{N}$ & $\mathrm{T}$ & $x$ & $x$ & $x$ & $x$ & $x$ \\
\hline 4. & hotel / hotel & sw & $x$ & $x$ & $x$ & $x$ & $x$ & $x$ \\
\hline 5. & archiwum / archive & $\mathrm{N}$ & $\mathrm{T}$ & - & + & - & + & $x$ \\
\hline 6. & $\begin{array}{l}\text { punkt przedszkolny / } \\
\text { day care for preschool children }\end{array}$ & $x$ & $x$ & $x$ & $x$ & $x$ & $x$ & $x$ \\
\hline 7. & hotel / hotel & $x$ & $x$ & $x$ & $x$ & $x$ & $x$ & $x$ \\
\hline 8. & gastronomia / catering outlet & $x$ & $\mathrm{~T}$ & - & $x$ & $x$ & $x$ & $\begin{array}{l}\text { składowanie materiałów / } \\
\text { stored materials }\end{array}$ \\
\hline 9. & $\begin{array}{l}\text { budynek mieszkalny } \\
\text { / residential building }\end{array}$ & $x$ & $\begin{array}{l}\text { spoczniki }<1,0 \mathrm{~m}-\mathrm{ZŻ} \mathrm{/} \\
\text { landings }<1.0 \mathrm{~m}-\mathrm{ZZZ}\end{array}$ & $x$ & $x$ & $x$ & $x$ & $\begin{array}{l}\text { składowanie materiałów / } \\
\text { stored materials }\end{array}$ \\
\hline 10. & biuro / office & $x$ & $x$ & - & - & - & - & $x$ \\
\hline 11. & $\begin{array}{l}\text { budynek mieszkalny } \\
\text { / residential building }\end{array}$ & sw & $x$ & - & + & - & - & $x$ \\
\hline 12. & biuro / office & $x$ & $\mathrm{x}$ & - & - & - & - & $x$ \\
\hline 13. & gastronomia / catering outlet & SW & $x$ & - & - & - & - & $x$ \\
\hline 14. & gastronomia / catering outlet & $x$ & $x$ & $x$ & $x$ & $\mathrm{x}$ & $x$ & $x$ \\
\hline 15. & muzeum / museum & $x$ & $x$ & - & + & - & + & $x$ \\
\hline 16. & muzeum / museum & $x$ & $x$ & - & + & - & - & $x$ \\
\hline 17. & gastronomia / catering outlet & $x$ & $x$ & - & - & - & - & $x$ \\
\hline 18. & galeria sztuki / art gallery & $x$ & $x$ & - & - & - & - & $x$ \\
\hline 19. & $\begin{array}{l}\text { budynek mieszkalny } \\
\text { / residential building }\end{array}$ & sw & $x$ & - & - & - & - & $x$ \\
\hline 20. & hotel / hotel & sw & $x$ & - & - & - & - & $x$ \\
\hline 21. & hotel / hotel & $x$ & $x$ & $x$ & $x$ & $x$ & $x$ & $x$ \\
\hline 22. & $\begin{array}{l}\text { budynek sakralny / } \\
\text { religious building }\end{array}$ & $x$ & $x$ & $x$ & $x$ & $x$ & $x$ & $x$ \\
\hline 23. & gastronomia / catering outlet & $x$ & $x$ & $x$ & $x$ & $x$ & $x$ & $x$ \\
\hline 24. & handel / retail outlet & $x$ & $x$ & - & - & - & - & $x$ \\
\hline
\end{tabular}

Oznaczenia w tabeli: $\mathrm{N}$ - niski, SW - średniowysoki, " ${ }^{-"}$ - nie występuje, " ${ }^{+"}$ - występuje, $\mathrm{X}$ - brak danych.

Key: $L$ - low-rise, M - mid-rise, "- $^{-}$not found, " + " - found, $X$ - no data.

Źródło: Opracowanie własne na podstawie materiałów KM PSP w Warszawie.

Source: Own elaboration on the basis of information of the Municipal Fire Brigade in Warsaw. 


\section{Badania ankietowe}

Do zarządców budynków zostało skierowane zapytanie w formie krótkiej ankiety dotyczące zagadnień z zakresu ochrony przeciwpożarowej [3]. Ankieta dotyczyła kwestii związanych z użytkowaniem:

- urządzeń i instalacji elektrycznych (bez grzewczych) (857),

- grzewczych urządzeń elektrycznych (57),

- urządzeń i instalacji grzewczych na paliwo stałe (846),

- urządzeń i instalacji grzewczych na paliwo ciekłe (28),

- urządzeń i instalacji grzewczych na paliwo gazowe (58)
W nawiasach powyżej podano liczbę pożarów spowodowanych przez przyczyny związane z użytkowaniem wymienionych urządzeń i instalacji na terenie województwa mazowieckiego w 2013 roku. Na podstawie tych danych sformułowano określonego rodzaju pytania ankietowe.

Ankiety dotyczące oceny stanu bezpieczeństwa pożarowego na Starym Mieście zostały wysłane do 13 zarządców nieruchomości mieszkalnych działających na terenie historycznego centrum Warszawy. Wyniki badań ankietowych przedstawiono w tabeli 2.

Tabela 2. Odpowiedzi uzyskane w badaniach ankietowych (budynki mieszkalne)

Table 2. Responses to the survey (residential buildings)

\begin{tabular}{|c|c|c|c|c|c|c|c|c|c|c|c|c|c|c|}
\hline $\begin{array}{l}\text { Lp. / } \\
\text { No. }\end{array}$ & Budynek nr / Building No. & 1. & 2. & 3. & 4. & 5. & 6. & 7. & 8. & 9. & 10. & 11. & 12. & 13. \\
\hline 1. & Kontrole techniczne instalacji / Technical installation inspections & $\mathrm{x}$ & $\mathrm{T}$ & $x$ & $\mathrm{~T}$ & $\mathrm{~T}$ & $\mathrm{~T}$ & $\mathrm{~T}$ & $\mathrm{~T}$ & $\mathrm{x}$ & $\mathrm{T}$ & $\mathrm{x}$ & $\mathrm{X}$ & $\mathrm{T}$ \\
\hline 2. & Książka budowlana / Building log-book & $\mathrm{x}$ & $\mathrm{T}$ & $\mathrm{x}$ & $\mathrm{T}$ & $\mathrm{T}$ & $\mathrm{T}$ & $\mathrm{T}$ & $\mathrm{T}$ & $\mathrm{x}$ & $\mathrm{T}$ & $\mathrm{x}$ & $\mathrm{X}$ & $\mathrm{T}$ \\
\hline 3. & Szkolenia przeciwpożarowe pracowników / Fire safety training for employees & $\mathrm{x}$ & $\mathrm{N}$ & $\mathrm{x}$ & $\mathrm{N}$ & $\mathrm{N}$ & $\mathrm{N}$ & $\mathrm{N}$ & $\mathrm{N}$ & $\mathrm{x}$ & $\mathrm{N}$ & $\mathrm{x}$ & $\mathrm{x}$ & $\mathrm{N}$ \\
\hline 4. & Czy są piwnice? / Are there basements? & $x$ & $\mathrm{~T}$ & $x$ & $\mathrm{~T}$ & $\mathrm{~T}$ & $\mathrm{~T}$ & $\mathrm{~T}$ & $\mathrm{~T}$ & $\mathrm{x}$ & $\mathrm{T}$ & $x$ & $x$ & $\mathrm{~T}$ \\
\hline 5. & Czy są użytkowane? / Are they used? & $x$ & $\mathrm{~T}$ & $x$ & $\mathrm{~T}$ & $\mathrm{~N}$ & $\mathrm{~T}$ & $\mathrm{~T}$ & $\mathrm{~N}$ & $x$ & $\mathrm{~T}$ & $x$ & $\mathrm{x}$ & $\mathrm{T}$ \\
\hline 6. & Jaki jest ich stan techniczny? / What is their technical condition? & $\mathrm{x}$ & Ś & $\mathrm{x}$ & Ś & $\mathrm{Ni}$ & $\mathrm{s}$ & Ś & $\mathrm{Ni}$ & $\mathrm{x}$ & ś & $\mathrm{x}$ & $\mathrm{x}$ & Ś \\
\hline 7. & System wykrywania pożaru / Fire detection system & $\mathrm{x}$ & $\mathrm{N}$ & $\mathrm{x}$ & $\mathrm{N}$ & $\mathrm{N}$ & $\mathrm{N}$ & $\mathrm{N}$ & $\mathrm{N}$ & $\mathrm{x}$ & $\mathrm{N}$ & $\mathrm{x}$ & $\mathrm{x}$ & $\mathrm{N}$ \\
\hline 8. & Instalacja gaśnicza / Fire-extinguishing system & $x$ & $\mathrm{~T}$ & $x$ & $\mathrm{~T}$ & $\mathrm{~N}$ & $\mathrm{~N}$ & $\mathrm{~T}$ & $\mathrm{~T}$ & $x$ & $\mathrm{~N}$ & $\mathrm{x}$ & $\mathrm{x}$ & $\mathrm{N}$ \\
\hline 9. & Czy dla budynku jest wykonana IBP? / Is there a fire plan for the building? & $\mathrm{x}$ & $\mathrm{T}$ & $x$ & $\mathrm{~N}$ & $\mathrm{~N}$ & $\mathrm{~T}$ & $\mathrm{~N}$ & $\mathrm{~N}$ & $\mathrm{x}$ & $\mathrm{N}$ & $\mathrm{x}$ & $x$ & $\mathrm{~N}$ \\
\hline 10. & Kiedy była aktualizowana? / When was it last revised? & $x$ & w & $x$ & - & - & w & - & - & $x$ & - & $x$ & $x$ & - \\
\hline
\end{tabular}

Oznaczenia w tabeli: T - tak, N - nie, B - bardzo dobry, Ś - średni, Ni - niezadowalający, 1 - w ciągu 1 roku, 2 - w ciągu 2 lat, W - wcześniej, X - brak danych. Key: $\mathrm{Y}$ - yes, $\mathrm{N}$ - no, E - excellent, $\mathrm{R}$ - reasonable, $\mathrm{U}$ - unsatisfactory, 1 - one year ago, 2 - 2 years ago, $\mathrm{E}$ - earlier, $\mathrm{X}$ - no data.

Źródło: Opracowanie własne.

Source: Own elaboration.

Ostatecznie otrzymano odpowiedzi od 8 z 13 zarządców, do których skierowano zapytania, co stanowi 61,5\%. Wynik ten można uznać za zadowalający w kontekście reprezentatywności wyników badania. Z uwagi na wielkość próby badawczej publikowane dane mają charakter informacyjny.

Przeprowadzone badania ankietowe wśród zarządców nieruchomości potwierdzają, iż w budynkach na terenie Starego Miasta instalacje są regularnie kontrolowane i sprawdzane. Odpowiedzi takich udzieliło 100\% ankietowanych, którzy odesłali wypełnione ankiety. Z uzyskanych informacji wynika, iż w budynkach na terenie historycznego centrum Warszawy są prowadzone książki budowlane. Takie informacje uzyskano od 100\% ankietowanych, którzy odesłali wypełnione ankiety. W wynikach ankiety należy zwrócić uwagę na brak szkoleń przeciwpożarowych oraz posiadanie instrukcji bezpieczeństwa pożarowego jedynie w dwóch budynkach. Na podstawie przeprowadzonego badania nie ma jednak możliwości precyzyjnego zdiagnozowania tego stanu rzeczy. Kolejne pytanie dotyczyło stanu technicznego piwnic (te części budynków były przedmiotem zainteresowania w programie HERITPROT). W wyniku analizy przesłanych odpowiedzi stwierdzono, iż w 75\% przypadków stan piwnic oceniany jest jako średni (drugi z trzech stopni oceny stanu technicznego), natomiast w 25\% przypadków - jako niezadowalający (najniższy z trzech stopni oceny stanu technicznego). Mimo że informacje uzyskane z badania ankietowego dotyczą subiektywnych opinii ano- nimowych osób, w ocenie autora można na ich podstawie założyć zasadność prowadzenia prac i projektów zmierzających do poprawy stanu technicznego i bezpieczeństwa pożarowego w obrębie piwnic i podziemi na terenie Starego Miasta.

Osobno badanie przeprowadzono wśród zarządców obiektów sakralnych na terenie Starego Miasta. Zapytania wysłano do wszystkich 5 administrowanych na tym terenie obiektów sakralnych. Ostatecznie otrzymano informacje zwrotne dla 4 budynków. Wyniki badań przedstawiono w tabeli 3. Analizując otrzymane wyniki, należy zwrócić uwagę, iż w zakresie podstawowych obowiązków technicznych oraz dokumentacji technicznych (kontrole instalacji i książki budowlane) sytuacja jest bardzo dobra. Prowadzenie książek i kontrolę instalacji potwierdzono w 100\% uzyskanych odpowiedzi. Nie są natomiast prowadzone szkolenia przeciwpożarowe wśród pracowników i obsługi w żadnym z analizowanych budynków. Instrukcje bezpieczeństwa pożarowego wykonano w 2 na 4 budynki, ale jest ona aktualna w jednym budynku. Dodatkowo otrzymano informację o zastosowaniu systemów sygnalizacji pożarowej (SSP) w dwóch przebadanych obiektach. Zastosowanie SSP w jednym z budynków wynika z obecności tego obiektu na liście GKZ. Jest to jedyny obiekt spośród przebadanych, gdzie taki obowiązek występuje. Instalacja hydrantowa znajduje się we wszystkich przebadanych budynkach, których administratorzy udzielili odpowiedzi na pytania ankietowe. 
Tabela 3. Odpowiedzi uzyskane $w$ badaniach ankietowych (budynki sakralne)

Table 3. Responses to the survey (religious buildings)

\begin{tabular}{|c|c|c|c|c|c|c|}
\hline $\begin{array}{l}\text { Lp. / } \\
\text { No. }\end{array}$ & Budynek nr / Building No. & 1. & 2. & 3. & 4. & 5. \\
\hline 1. & Kontrole techniczne instalacji / Technical installation inspections & $\mathrm{T}$ & $\mathrm{T}$ & $\mathrm{T}$ & $x$ & $\mathrm{~T}$ \\
\hline 2. & Książka budowlana / Building log-book & $\mathrm{T}$ & $\mathrm{T}$ & $\mathrm{T}$ & $\mathrm{x}$ & $\mathrm{T}$ \\
\hline 3. & Szkolenia przeciwpożarowe pracowników / Fire safety training for employees & $\mathrm{N}$ & $\mathrm{N}$ & $\mathrm{N}$ & $x$ & $\mathrm{~N}$ \\
\hline 4. & Czy są podziemia? / Are there any basements? & $\mathrm{T}$ & $\mathrm{T}$ & $\mathrm{T}$ & $\mathrm{x}$ & $\mathrm{T}$ \\
\hline 5. & Czy są użytkowane? / Are they used? & $\mathrm{T}$ & $\mathrm{T}$ & $\mathrm{T}$ & $\mathrm{x}$ & $\mathrm{T}$ \\
\hline 6. & Jaki jest ich stan techniczny? / What is their technical condition? & B & B & $S$ & $x$ & B \\
\hline 7. & Instalacje przeciwpożarowe / Firefighting systems & $\mathrm{T}$ & $\mathrm{T}$ & $\mathrm{T}$ & $\mathrm{x}$ & $\mathrm{T}$ \\
\hline 8. & Jakie? / What kind of systems? & $\mathrm{H}$ & $\mathrm{S}, \mathrm{H}$ & $\mathrm{H}$ & $\mathrm{x}$ & $\mathrm{S}, \mathrm{G}, \mathrm{H}$ \\
\hline 9. & Czy dla budynku jest wykonana IBP? / Is there a fire plan for the building? & $\mathrm{T}$ & $\mathrm{T}$ & $\mathrm{N}$ & $x$ & $\mathrm{~N}$ \\
\hline 10. & Kiedy była aktualizowana? / When was it last revised? & W & 1 & - & $x$ & - \\
\hline
\end{tabular}

Oznaczenia w tabeli: T - tak, N - nie, B - bardzo dobry, Ś - średni, Ni - niezadowalający, S - system SSP, G - system wykrywczy gazu, H - hydranty 1 - w ciągu 1 roku, 2 - w ciągu 2 lat, $\mathrm{W}$ - wcześniej, $\mathrm{X}$ - brak danych.

Key: Y - yes, N - no, E - excellent, R - reasonable, U - unsatisfactory, F - FAS system, G - gas detection system, $\mathrm{H}$ - hydrants 1 - one year ago, $2-2$ years ago, $E$ - earlier, $X-$ no data.

Źródło: Opracowanie własne.

Source: Own elaboration.

Analiza otrzymanych wyników dotyczących budynków administrowanych przez organizacje kościelne w szerszym kontekście pozwala stwierdzić, iż zabezpieczenie przeciwpożarowe $w$ tego typu obiektach jest realizowane na poziomie wyższym niż w budynkach zarządzanych przez administratorów wspólnot mieszkaniowych. Jest prawdopodobne, iż wynika to z instytucjonalnego charakteru tego typu obiektów. Brak obecności systemu sygnalizacji pożarowej (SSP) nie musi oznaczać nieakceptowalnego poziomu zabezpieczenia budynku. System ten występuje w obiekcie, dla którego jest on wymagany listą GKZ. W pozostałych obiektach nie jest wymagany przepisami prawa bezpośrednio (rozporządzenie) lub pośrednio (lista GKZ). W każdym przypadku zastosowanie SSP poprawia bezpieczeństwo pożarowe, ale ocena zasadności jego zastosowania (pod kątem technicznym i ekonomicznym) nie jest możliwa bez przeprowadzenia analizy technicznej stanu bezpieczeństwa pożarowego.

Należy docenić fakt dbałości o piwnice i podziemia. W większości przypadków ich stan jest uznawany za "bardzo dobry" i tylko w jednym przypadku za "średni". Oznacza to prawdopodobnie, iż te części budynków zostały zaadaptowane do funkcji związanych z przeznaczeniem obiektów, w których występują i ewentualne zagrożenia są w tych przestrzeniach kontrolowane.

Negatywnie należy natomiast ocenić brak szkoleń przeciwpożarowych. Nie są one realizowane w żadnym z badanych budynków. W tego typu sytuacjach praktyczne stosowanie zasad bezpieczeństwa zawartych $w$ instrukcji bezpieczeństwa pożarowego jest bardzo nieefektywne. W związku z powyższym wskazane jest przeprowadzenie działań informacyjnych dotyczących podniesienia świadomości w zakresie zagrożeń pożarowych.

\section{Ocena przygotowania operacyjnego}

Dostęp do budynków przy wykorzystaniu dróg pożarowych

Z uwagi na układ urbanistyczny wszystkie drogi na Starym Mieście są drogami pożarowymi. Na tym terenie obowiązuje zakaz ruchu oraz ograniczony postój' i występuje odpowiednie oznakowanie. Straż miejska jest zobowiązana do kontroli przestrzegania tych ograniczeń.

Na postawie przeprowadzonej wizji lokalnej oraz pomiarów parametrów technicznych ${ }^{2}$ została opracowana mapa dróg pożarowych na terenie historycznego centrum Warszawy [3]. Opracowaną mapę pokazano na rycinie 4 . Kolor zielony oznacza drogi pożarowe zgodne z obecnie obowiązującymi wymaganiami $[5, \S 12-16]$, gdzie nie występują utrudnienia związane z dostępem do obiektów budowlanych. Kolor pomarańczowy na mapie oznacza występujące trudności z przejazdem (drogi węższe niż wymagane przepisami $4 \mathrm{~m}$ lub o promieniu skrętu poniżej $11 \mathrm{~m}$ ). Przejazd nimi jest możliwy, natomiast może trwać dłużej niż w przypadku dróg zgodnych z wymaganiami. Należy uznać, iż prowadzenie działań ratowniczo-gaśniczych jest możliwe we wszystkich obiektach Starego Miasta, natomiast dla budynków zlokalizowanych w obrębie ulic oznaczonych kolorem czerwonym będzie ono utrudnione, $z$ uwagi na oddalenie stanowisk ratowniczych i gaśniczych od samochodów PSP. Najtrudniejsza sytuacja w zakresie dróg pożarowych występuje w północnej części obszaru, gdzie drogi wjazdowe na teren Starówki są zlokalizowane głównie od strony południowo-wschodniej (ul. Piekarska, Plac Zamkowy i ul. Celna). Natomiast potencjalne dojazdy od strony zachodniej i północnej

\footnotetext{
'Zarządzenie Nr 4143/2010 Prezydenta Miasta Stołecznego Warszawy. ${ }^{2} \mathrm{~W}$ wizji lokalnej uczestniczyli studenci SGSP $\mathrm{w}$ ramach zajęć z przedmiotu bezpieczeństwo pożarowe budynków.
} 


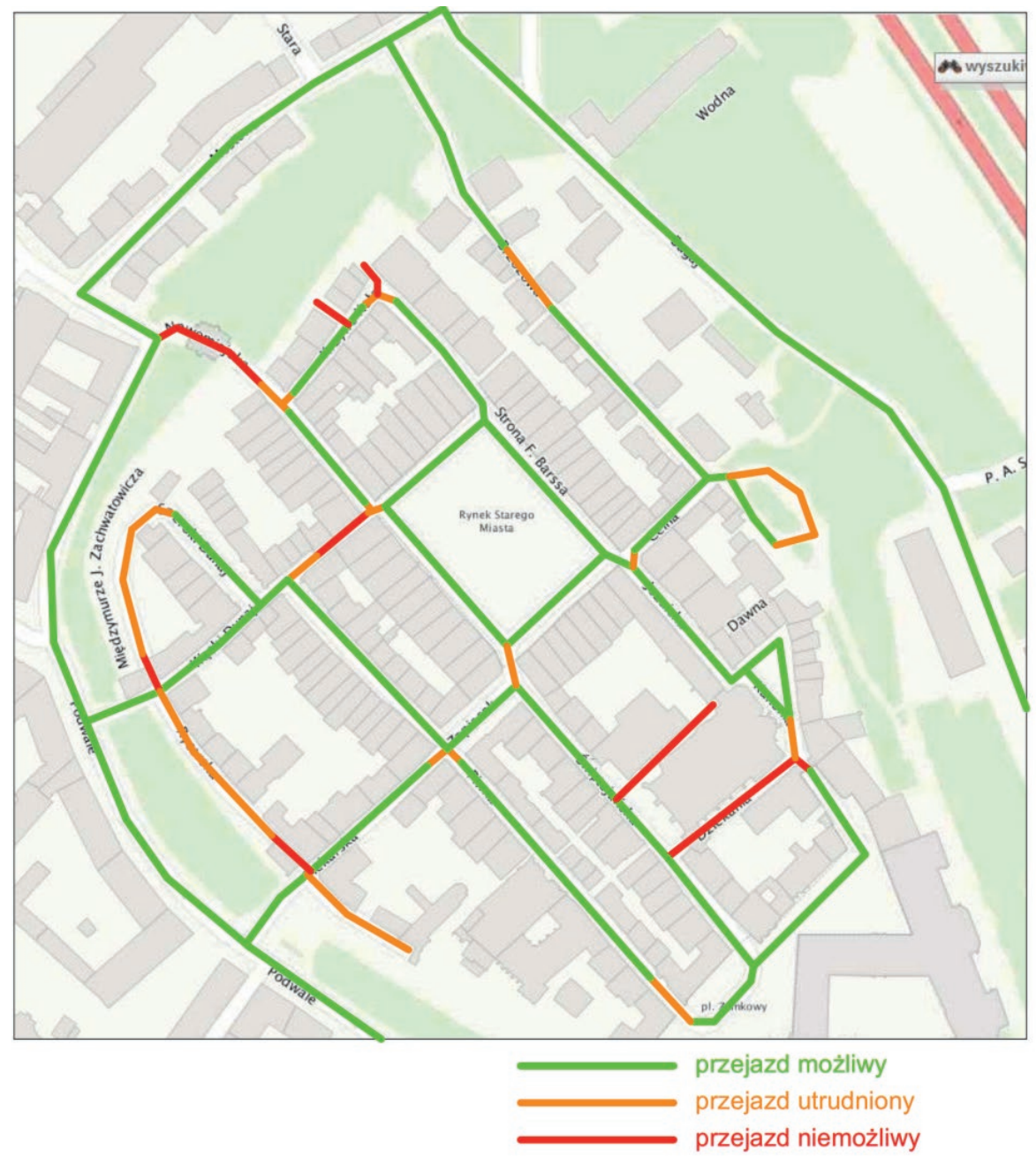

Rycina 4. Plan Starego Miasta w Warszawie z oznaczoną przejezdnością dróg pożarowych

Figure 4. Plan of the Old Town in Warsaw with fire access road passability marked

Źródło: Opracowanie własne.

Source: Own elaboration.

(ul. Wąski Dunaj i Nowomiejska) są nieprzejezdne. Dodatkowo w tych miejscach odległość budynków od przejezdnej ulicy Podwale jest zbyt duża, więc konieczny jest dojazd od południa lub wschodu i dojazd przez ulice otaczające Rynek Starego Miasta.

Z uwagi na uwarunkowania historyczne i techniczne nie ma możliwości przebudowy układu komunikacyjnego historycznego centrum Warszawy i należy wykorzystać inne metody w celu zwiększenia efektywności prowadzenia potencjalnych działań ratowniczo-gaśniczych:

1. Szczegółowe zapoznanie strażaków z JRG 4, której rejon działania obejmuje m.in. obszar Starego Miasta, z możliwościami prowadzenia działań na całym terenie Starówki (np. poprzez symulację zagrożenia w ramach ćwiczeń ratowniczo-gaśniczych w rejonie operacyjnym).

2. Wyposażenie JRG $4 \mathrm{w}$ lekki samochód gaśniczy, który zapewni wystarczającą zwrotność na wąskich uliczkach Starego Miasta, wyposażony w długą linię tzw. „szybkiego natarcia" oraz w zwiększoną liczbę węży pożarniczych. Warto rozważyć również wyposażenie takiego samocho- du w pompę wysokociśnieniową, która zwiększa efektywność procesu gaszenia przy zmniejszonym zużyciu wody.

3. Prowadzenie szkoleń specjalistycznych dla strażaków JRG 4 uwzględniających specyfikę działań gaśniczych oraz akcji ewakuacyjnych na terenie Starówki: dużą odległość obiektów od samochodów, brak możliwości wykorzystania drabin i podnośników, wąskie i drewniane klatki schodowe oraz brak wolnej przestrzeni na organizowanie stanowisk ratowniczo-gaśniczych i punktów zbiórki do ewakuacji.

\section{Przeciwpożarowe zaopatrzenie w wodę}

Zgodnie z informacją otrzymaną od Miejskiego Przedsiębiorstwa Wodociągów i Kanalizacji wszystkie oznaczone na mapie hydranty znajdujące się na terenie Starego Miasta (57 szt.) są sprawne i spełniają wymagania obowiązujących przepisów. Ich lokalizację przedstawiono na rycinie 5. Mapa z aktualnym rozmieszczeniem hydrantów zawiera lokalizację hydrantów sprawnych, konserwowanych i zapewniających wymagane parametry hydrauliczne. 
Ich rozmieszczenie jest zgodne z wymaganiami w zakresie odległości od budynków. Ich gęstość rozmieszczenia jest nawet większa niż wynika to z przepisów przeciwpożarowych. Występują jednak drobne niezgodności w zakresie minimalnych odległości od chronionych obiektów, które są wynikiem bardzo gęstej zabudowy i małej szerokości dróg pożarowych. Niezgodności są rekompensowane dostępnością 2-3 kolejnych hydrantów w zasięgu działania.
Nierozwiązana pozostaje kwestia hydrantów nieczynnych. Z doświadczenia własnego autora wynika, iż ten problem nie dotyczy w takiej skali pozostałych dzielnic Warszawy. Mapka zawiera wyłącznie hydranty sprawne, natomiast nie umożliwia identyfikacji hydrantu sprawnego, który znajduje się w bezpośrednim sąsiedztwie hydrantu wycofanego z użytkowania. Jedynym możliwym rozwiązaniem tego problemu jest usunięcie niesprawnych hydrantów (usunięcie lub wymiana klap dostępowych) z ulic Starego Miasta.

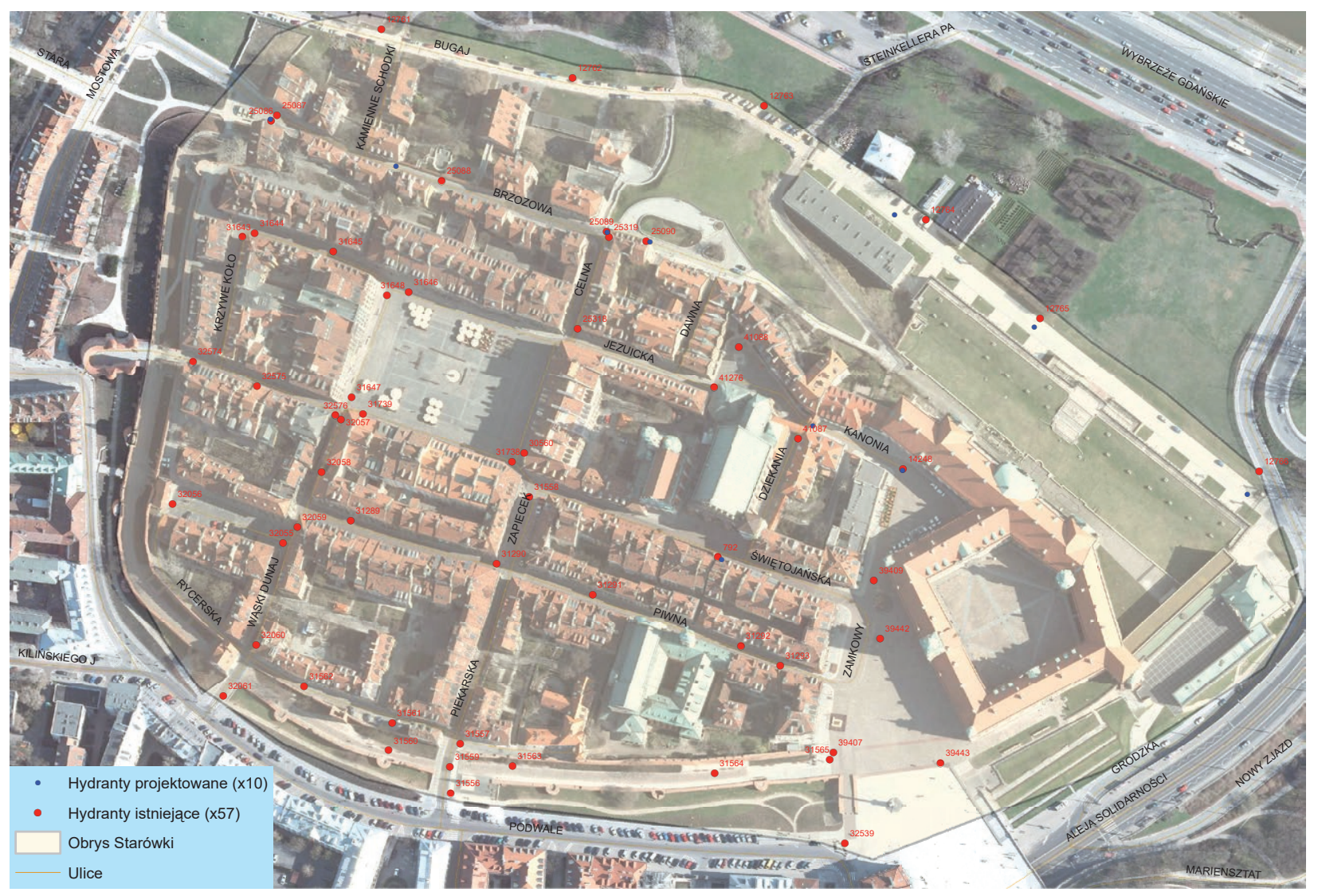

Rycina 5. Plan Starego Miasta w Warszawie z oznaczoną lokalizacją hydrantów

Figure 5. Plan of the Old Town in Warsaw with fire access roads marked

Źródło: Informacja otrzymana od MPWiK w dniu 27.06.2014.

Source: Information obtained from MPWiK on the $27^{\text {th }}$ of June 2014.

Działania te powinny stanowić priorytet dla MPWiK. Są one możliwe do realizacji w ramach prac bieżących, ponieważ zarówno z wizji lokalnej, jak i przestawionej mapy (hydranty projektowane) wynika, iż prace $w$ tym zakresie prowadzone są sukcesywnie. Skutecznym działaniem doraźnym byłoby wyraźne oznakowanie nieczynnych hydrantów (np. kolorem żółtym) oraz przekazanie informacji o takim działaniu do jednostek PSP.

\section{Propozycja poprawy bezpieczeństwa pożarowego miejskich starówek}

\section{Wyposażenie budynków w mgłowe agregaty gaśnicze}

Trudność w osiągnięciu poprawy skuteczności gaszenia pożarów w budynkach Starego Miasta w Warszawie polega na konieczności osiągnięcia kompromisu pomiędzy dwoma pozornie wykluczającymi się celami:
- zapewnienia skutecznego sposobu gaszenia cennych zabytków stanowiących wyposażenie budynków bez narażenia ich na szkodliwy wpływ środka gaśniczego,

- zapewnienie bezpiecznego środowiska gazowego w trakcie ewakuacji ludzi z budynku przy wykorzystaniu pionowych dróg ewakuacyjnych.

Optymalne środowisko dla rozwoju pożaru (dostęp tlenu, brak obecności związków chemicznych) jest jednocześnie najbardziej bezpieczne w trakcie ewakuacji. Każda ingerencja ograniczająca rozwój pożaru (obniżanie stężenia tlenu, stosowanie związków chemicznych lub gazów gaśniczych) może jednocześnie stanowić zagrożenie dla ludzi w trakcie ewakuacji w tym środowisku. Najbardziej popularnym medium gaśniczym, które przy minimalnej ingerencji w elementy wyposażenia nie ogranicza bezpiecznej ewakuacji, jest woda w postaci mgły gaśniczej. 
Propozycja poprawy bezpieczeństwa dotyczy wyposażenia budynków (ze szczególnie cenną tkanką zabytkową) oraz ewentualnie samochodów gaśniczych w mgłowe agregaty gaśnicze, które umożliwiają skuteczną akcję gaśniczą przy minimalnym zużyciu wody. Działanie takie znacznie ogranicza ryzyko uszkodzenia zabytków dzięki:

- szybszemu ugaszeniu źródła ognia,

- minimalizacji strat związanych z bezpośrednim oddziatywaniem wody.

Podstawą mechanizmu gaśniczego mgły wodnej jest najdrobniejsze rozproszenie wody w celu uzyskania możliwie największej powierzchni zewnętrznej, która:

- przejmuje bardzo szybko energię powstająca w wyniku spalania, dzięki czemu nie powoduje ona podtrzymywania procesu palenia,

- przez bardzo szybkie przechodzenie z fazy ciekłej w stan pary i związany z tym znaczny wzrost objętości $(1 \mathrm{I}$ wody = = $1720 \mathrm{I}$ pary) znacznie zmniejsza zawartość tlenu wewnątrz ogniska pożaru, co wpływa istotnie na hamowanie procesu spalania.

Ustalenie szczegółów dotyczących parametrów oraz lokalizacji mgłowych agregatów gaśniczych w budynkach na analizowanym terenie powinno zostać poparte analizą dotychczasowych działań gaśniczych.

\section{Korekta wymagań prawnych w zakresie Instrukcji \\ Bezpieczeństwa Pożarowego}

Jednym ze sposobów poprawy bezpieczeństwa pożarowego oraz przygotowania operacyjnego jest szczegółowa analiza warunków ochrony przeciwpożarowej oraz organizacji ochrony przeciwpożarowej na etapie funkcjonowania budynku przed wystąpieniem zdarzenia niekorzystnego. W tym celu dla wybranej grupy obiektów przygotowuje się dokumentację $w$ formie instrukcji bezpieczeństwa pożarowego, zawierającą część opisową oraz plany graficzne z uwzględnieniem istotnych elementów ochrony przeciwpożarowej. W celu uwzględnienia specyfiki i szczególnego charakteru budynków zabytkowych możliwe jest wprowadzenie pewnej korekty obowiązujących przepisów, która rozszerzy obowiązek opracowywania instrukcji bezpieczeństwa pożarowego na budynki zabytkowe oraz nieznacznie zmieni tematyczny zakres instrukcji. Aby to zrealizować, w rozporządzeniu [4] po $\S 6$ ust. 1 powinien pojawić się ust. $2 \mathrm{w}$ brzmieniu:

"2. Właściciele, zarządcy lub użytkownicy obiektów bądź ich części stanowiących odrębne strefy pożarowe, wzniesionych przed 1939 rokiem lub wskazanych przez właściwego miejscowo wojewódzkiego konserwatora zabytków, zapewniają i wdrażają instrukcję bezpieczeństwa pożarowego, zawierającą wszystkie punkty wymienione w $\S 6$ ust. 1 oraz dodatkowo:

1) podstawę wykonania Instrukcji (data wzniesienia, nakaz WKZ),

2) szczegółowe zestawienie elementów budynku i wyposażenia uznane za cenne $w$ związku $z$ istotnym wpływem na dziedzictwo narodowe i historyczne,

3) sposoby postępowania na wypadek pożaru i innego zagrożenia, ze szczególnym uwzględnieniem zasad ochrony i zabezpieczenia zabytkowych elementów i wyposażenia,

4) warunki i organizację ewakuacji zabytkowego wyposażenia i eksponatów oraz praktyczne sposoby ich sprawdzania,
5) wskazanie osób odpowiedzialnych za zabytkowe wyposażenie i eksponaty,

6) plany obiektów obejmujące usytuowanie tych obiektów oraz terenu przyległego, z uwzględnieniem graficznych danych dotyczących w szczególności:

- lokalizacji i charakterystyki elementów konstrukcji, wyposażenia i eksponatów o charakterze zabytkowym,

- warunków ewakuacji wyposażenia i eksponatów o charakterze zabytkowym, ze wskazaniem kierunków i wyjść ewakuacyjnych,

- wskazanie zasad ochrony zabytkowego wyposażenia i eksponatów przed działaniami przestępczymi mogącymi wystąpić w trakcie nadzwyczajnego zdarzenia oraz (we wskazanych przypadkach) zawierać konieczność ich uzgodnienia z właściwą miejscowo KW Policji".

Kolejne ustępy w §6 pozostają bez zmian, z tym że każdy $\mathrm{z}$ nich ma numer większy o $1 \mathrm{w}$ stosunku do obecnej numeracji.

Rozwiązania realizowane w innych państwach

Przykładem systemowego rozwiązania poprawy bezpieczeństwa pożarowego skupisk zabytkowych jest program realizowany w Norwegii w latach 1993-1997, dotyczący poprawy bezpieczeństwa pożarowego wyselekcjonowanych kościołów [6]. Ponad 400 kościołów wybudowanych przed 1800 rokiem otrzymało możliwość uzyskania rządowego grantu na wprowadzenie rozwiązań z zakresu ochrony przeciwpożarowej:

- instalacji piorunochronnej,

- systemu antywłamaniowego (eliminującego podpalenia jako przyczynę pożaru),

- systemu sygnalizacji pożarowej SSP,

- hydrantów zewnętrznych wyposażonych w węże mrozoodporne.

Najbardziej cenne zabytkowo kościoły otrzymały dodatkowo możliwość wyposażenia w urządzenia gaśnicze (zraszaczowe i mgłowe).

W porównaniu do warunków polskich, rozwiązania stosowane w Norwegii są zbliżone, wyłączając hydranty z wężami mrozoodpornymi (względy klimatyczne). Na szczególną uwagę zasługuje fakt zaleceń stosowania rozwiązań gaśniczych (m.in. opisanych w punkcie 5.2) z uwagi na możliwość szybkiego rozwoju pożaru w drewnianych atriach i wieżach, które są charakterystyczne dla zabytkowych budowli sakralnych.

\section{Wnioski}

Wrażliwa tkanka zabytkowa związana z obiektami budowlanymi oraz dziełami sztuki w większości europejskich miast zlokalizowana jest w miejskich starówkach. Jednocześnie sam układ zagospodarowania terenu tych obszarów jest objęty ścisłą ochroną konserwatorską. Powoduje to szereg problemów związanych z zabezpieczeniem przeciwpożarowym występujących tam obiektów i zabytków oraz przygotowaniem operacyjnym terenu do prowadzenia akcji ratowniczo-gaśniczej.

Celem artykułu była ocena bezpieczeństwa pożarowego oraz przygotowania operacyjnego Starego Miasta w Warszawie. Cel ten osiągnięto przy wykorzystaniu materiałów zgromadzonych podczas pracy przy programie HERITPROT, badań ankie- 
towych, wizji lokalnej, analizy statystycznej danych KG PSP, KM PSP Warszawy oraz analizy literaturowej. Trudności związane $\mathrm{z}$ problematyką przedstawioną $\mathrm{w}$ artykule można pokonywać z wykorzystaniem rozwiązań technicznych lub uwarunkowań prawnych. Przykłady pozytywnych działań w obydwu wymienionych obszarach zawarto w ostatniej części artykułu, po dogłębnej analizie tematyki. Wykazano, iż istnieją narzędzia pozwalające poprawiać stan bezpieczeństwa pożarowego w starówkach miejskich oraz przydatne do polepszenia przygotowania tych

\section{Literatura}

[1] A Good Practice Manual For Fire Protection In World Heritage Cities, HERITPROT Project, Tenerife 2014.

[2] Warszawa na Liście Światowego Dziedzictwa UNESCO, Strona internetowa Biura Stołecznego Konserwatora Zabytków, http:// zabytki.um.warszawa.pl/content/warszawa-na-liscie-swiatowego-dziedzictwa-unesco [dostęp: 24.05.2017].

[3] Plan Działania i Plan Wdrażania dobrych praktyk dla Historycznego Centrum Warszawy HERITPROT, Warszawa 2015.

[4] Rozporządzenie Ministra Spraw Wewnętrznych i Administracji z dnia 7 czerwca 2010 r. w sprawie ochrony przeciwpożarowej budynków, innych obiektów budowlanych i terenów (Dz.U. Nr 109, poz. 719).

[5] Rozporządzenie Ministra Infrastruktury z dnia 12 kwietnia 2012 r. w sprawie warunków technicznych jakim powinny odpowiadać budynki i ich usytuowanie (Dz.U. 2002 poz. 690).

[6] Karlsen E., Fire protection of Norwegian cultural heritage, [electr. doc.] http://www.arcchip.cz/w04/w04_karlsen.pdf [accessed: 24.05.2017]. obszarów do prowadzenia akcji ratowniczo-gaśniczej. W celu wdrożenia konkretnych rozwiązań, należy ogólne wnioski i wytyczne zawarte w niniejszym artykule poprzeć analizą akcji gaśniczych prowadzonych na terenie Starego Miasta oraz dostosować je do występujących w konkretnym budynku warunków brzegowych. Dodatkowo kompleksowa ocena stanu dróg pożarowych i przeciwpożarowego zaopatrzenia w wodę może być bezpośrednio wykorzystana do działań operacyjnych Komendy Miejskiej PSP w Warszawie.

MŁ. BRYG. DR INŻ. MARIUSZ PECIO - absolwent studiów II stopnia na Wydziale Inżynierii Bezpieczeństwa Pożarowego SGSP. W 2008 roku obronił doktorat w Akademii Finansów w Warszawie (praca na temat ryzyka pożarowego w ubezpieczeniach ogniowych). Od 2001 roku zatrudniony na Wydziale Inżynierii Bezpieczeństwa Pożarowego SGSP, obecnie na stanowisku adiunkta. Autor publikacji, referatów na konferencjach naukowych, uczestnik projektów badawczych krajowych i międzynarodowych. Rzeczoznawca ds. zabezpieczeń przeciwpożarowych, autor ekspertyz, dokumentacji projektowych i technicznych z zakresu ochrony przeciwpożarowej w budownictwie. 

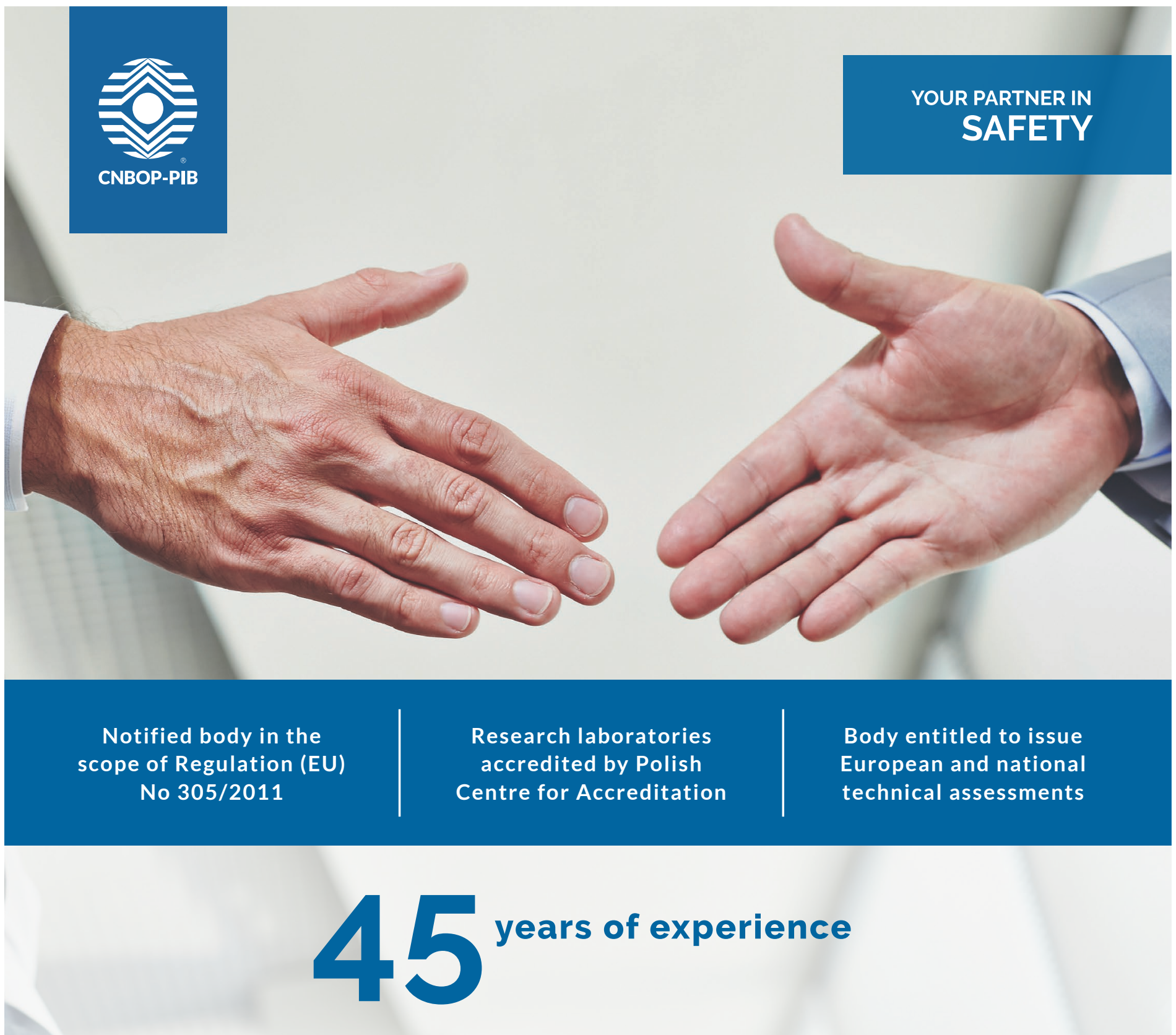

We act to the benefit of public safety in Poland, especially in the scope of fire protection, emergency management, civil protection and civil defense

\section{Our services}

- Admittance of fire protection products

- European and national certification of construction products

- Voluntary certification of fire protection products

- Certification of entities offering fire protection services

- European and national technical opinions

- Technical opinions and expertise
- Testing of innovative products

- Test of:

- equipment of fire protection units

- fixed firefighting systems

- chemicals and fires

- combustion and explosion processes

- firefighting systems and automatics

- $\quad$ Fire protection training 